Mohammed Ahmed Ibrahim, Doctor of Economics, Head of Department, Academician of the Department of Banking and Finance, Federal University Dutse, Jigawa State-Nigeria

ORCID ID: 0000-0002-5505-1417

e-mail: nafAnjka19@gmail.com

Abubakar Magaji Adamu, Doctor of Investment Management, Head of Department, Academician of the Department of Business Administration, Federal University Dutse, Jigawa State-Nigeria

ORCID ID: 0000-0001-7726-1696

e-mail: magajiaa@fud.edu.ng

Garba Sunusi, Doctor of Accounting, Academician of the Department of Accounting, Federal University Dutse, Jigawa State-Nigeria

ORCID ID: 0000-0002-8263-5370

Damamusau M. S., Doctor of Accounting, Head of Department, Academician of the Department of Taxations, Federal University Dutse, Jigawa State-Nigeria Sudan

Salisu Y., Student at the Faculty of Economics Sciences and Management, University of Bakht-Al Ruda,

\title{
Influence of Factors on Crop Cultivation Efficiency: Regional Aspect
}

Introduction. Literature was extensively reviewed in crop cultivation and other related fields for a better understanding of past, present and future needs in the study area. Although their relationships have generated considerable both farmers as well as public and scholarly interest. Agriculture is essential to economic growth in Nigeria and it is a major source of employment and poverty reduction as well as contributing significantly towards the gross domestic products.

Purpose. The purpose of this study is to investigate the relationships between bank loan supply, land size, technology, cost-plus and crop cultivation in Nigeria. Based on a theoretical consideration this study was proposed to examine these relationships to improve cultivation.

Method. A cross-sectional survey design was adopted and the unit of analysis was the individual farmer in Nigeria. The study employed a systematic random sampling technique in data collection, with a sample size of 764 farmers. Partial Least Squares (PLS) algorithm and bootstrap techniques were used to test the stated hypotheses.

Result and Recommendation. The findings of this study are that bank loan supply, technology, cost-pus have a direct and significant positive relationship with Crop cultivation, while, land size is not a predictor of Crop cultivation in Nigeria. Finally, the study's implications for theory and practice, conclusions as well as direction for future research were provided and discussed.

Keywords: Bank Loan Supply; Cost-plus; Land Size; Technology; Financial Institutions.

\section{удк 332.1}

Мохаммед А. I., доктор економічних наук, завідувач кафедри, академік кафедри банківської справи та фінансів, Федеральний університет Дуце, штат Джиґава, Нігерія

Абубакар М. А., доктор економічних наук, завідувач кафедри, академік кафедри ділового адміністрування, Федеральний університет Дуце, штат Джиґава, Нігерія

Гарба С., доктор економічних наук, академік кафедри бухгалтерського обліку, Федеральний університет Дуце, штат Джигава, Нігерія

Дамамусов М. С., доктор економічних наук, завідувач кафедри, академік кафедри оподаткування, Федеральний університет Дуце, штат Джигава, Нігерія Судан

Салісу ю., студент факультету економічних наук та менеджменту, Університет Бахт-Аль-Руда,

\section{Вплив факторів на ефективність вирощування сільськогосподарських культур: регіональний аспект}

Розглянуто світовий досвід у галузі вирощування сільськогосподарських культур для кращого розуміння минулих, теперішніх та майбутніх потреб у досліджуваній області. Доведено, що моніторинг впливу факторів на ефективність вирощування сільськогосподарських культур викликає значний інтерес фермерів, громадський та 
науковий інтерес. Обгрунтовано, що сільське господарство має важливе значення для економічного зростання Нігерії та розглядається як головне джерело зайнятості населення, зменшення бідності, а також джерело формування валового внутрішнього продукту. Нігерія характеризується сприятливими кліматичними умовами для сільськогосподарського виробництва, однак фермери стикаються з проблемами недостатнього виробництва фермерськими господарствами, поганого доступу до банківських кредитів, недостатньої кількості технологій, застарілої сільськогосподарської техніки та обладнання. Метою цього дослідження є аналіз взаємозв'язку між пропозицією банківського кредиту, розміром землі, технологіями, рентабельністю та вирощуванням врожаю в Нігерії. У дослідженні було використано систематизовану методику випадкового відбору проб для збору даних, розмір вибірки - 764 фермерські господарства. Алгоритм часткових найменших квадратів було використано для перевірки заявлених гіпотез. Результати цього дослідження полягають у тому, що пропозиція банківських позик, технологія, гнучкість мають прямий та значний позитивний зв'язок з ефективністю вирошування сільськогосподарських культур, тоді як розмір земель не є фактором сильного впливу на ефективність вирощування сільськогосподарських культур у Нігерії. Було сформовано наслідки дослідження для теорії та практики, висновки, а також напрями майбутніх досліджень. установи.

Ключові слова: пропозиція банківських позик; додаткові витрати; розмір землі; технологія; фінансові

Introduction. Crop cultivation which is popularly known as agricultural production can be seen as an act of soil cultivation for the growth of plant and management for poverty reduction and economic growth as it serves as a solution to the global food constraints mostly by the developing economies. It equally stands as a major source of income and full-time employment to the majority of African countries (Chisasa [1]; Ogunbado \& Ahmed [2]). Likewise, the economic growth of the most populous country of Africa called Nigeria is almost dependent on agricultural production. It was the fifth country in Agricultural output according to World rankings for the year 2018 (Index Mundi. Furthermore, by January 1st 2020, Nigerian population was estimated at 206.14 Million ranking seventh in the world, while 70 percent of this population remain solidly depended on agriculture as their main source of socio-economic priorities as such includes: income, food, employment, market, and social amenities among others (Philip, Nkonya, Pender \& Oni Nkonya [3]; World Population Review [4]).

Atagana and Kanu [5], viewed that bank loan supply and farmland remain key players towards the advancement of Crop cultivation. As the name implies bank loan supply is the direct financial aspect. While land size is the top layer of the earth's surface that contained nutrients for the growth of plants. It is also provided space for livestock, poultry, and fisheries as well as agribusiness activities (Chamber [6]). In a contrasting view, Collier and Dercon [7], stipulated that technology investment is one of the best targets toward supporting Crop cultivation. These facilities include tractors, herbicides, harvesters, farmers' education, and training, modern storage facilities, good road, transportation, and communication, among others (Ahungwu, Haruna \& AbdusSalam [8]). Despite the importance of Crop cultivation in the economic growth of Nigeria as well as the initiatives of both public and private organizations toward improving the sector. Yet, the problem of understanding the relationship between crop production with bank loan supply, cost plus, land size, and technology is stated since after the period of the oil boom in the 1970s.

Nigeria is blessed with the abundance of both human and natural resources. It has favourable climatic conditions for supporting agricultural production with 84 million arable land hectares. Farmers are facing the problems of inadequate farm input, output, and services which resulted in poor access to bank loan supply, sales of land size and insufficient technology such as inadequate farm machinery and equipment (Ogunbado \& Ahmed [2]; Index mundi). In line with the argument of the CobbDouglas theory of the production function, it revealed that sufficient production input is subject to the proportional and significant increase in the production output (Chambers [6]; Chisasa [1]). Similarly, the theory of economic development indicated that financial intermediaries remain a key facilitator and a player towards attaining the economic growth of the productive sectors (King \& Levine [9]). However, farmers suffer from the issues related to insufficient bank loan supply, cost plus, land size and technology to the extent that farmers are abandoning the practice of agriculture. Based on these this paper developed the following research objectives.

The research is set to examine the relationship between farm loan supply, cost-plus land size, technology, and crop cultivation. Specifically, the research aims to achieve the following objectives:

1. To examine the relationship between bank loan supply and Crop cultivation in Nigeria.

2. To examine the relationship between land size and Crop cultivation in Nigeria.

3. To examine the relationship between technology and Crop cultivation in Nigeria.

4. To examine the relationship between Cost-plus and Crop cultivation in Nigeria

Literature review and the problem statement. This study defined crop cultivation as an act of soil cultivation for food supply and raw materials to the industries. It is also a science of crop production, forest management, caring of animals; fishery management, processing, and marketing with the aim of sustainable living and economic growth. Equally, agriculture can be served as the machinery of achieving economic growth through utilization of the soil for the provision of food to the man, feed to the animals and preservation of forest (Akoum [10]; Chisasa [11]). Similarly, it can be defined as an act of soil cultivation for food supply and raw materials to the industries. It is also a science of crop production, forest management, caring of animals; fishery management, 
processing, and marketing of crop cultivation. It is a study that deals with the soil utilization for food to the man and feeds to the animals and preservation of forest for human satisfaction and economic growth (Ayegba \& Ikani [12]; Chisasa [1]).

Consequently, it can be regarded as a production strategy of the transformation of combined factors to create marketable crop cultivation. It also remains a sustainable mode of living in terms of food supply, income, employment, market, and industries (Anthony [13]). It is a central driver for poverty eradication and economic growth through the supply of Crop cultivation and the market. Therefore, Crop cultivation can be seen as an outcome of land cultivation of the land and animal rearing. More so, it is a yield of all forms of farming activities as well as output processing, marketing and consumption for sustainable living and economic growth (Chamber [6]).

Research results. Loan defined is an important instrument for improving the welfare of the poor directly through smoothening and reduces their vulnerable shortterm income. It is also the way and manner of enhances the productive capacity of the poor through financing their investment concerning human and physical capital (Anthony [13]). Besides, bank loan supply can be defined as a total amount of money available to lend out to the needy individual or group of farmers with the agreement of repayment over some time in a future (Chisasa [1]). It is equally, recognized as an outflow of the fund to the needy farmer to make the repayment with some additional fund or reward for the utilization of the fund over a while. And, it is can be a procedure of gaining command of money, goods, and services for agricultural activities based on repayment conditions (Simtowe \& Lestari [14]).

More so, bank loan supply is recognised as the main requirement and core factor in the development and advancement of Crop cultivation and economic growth (Ahiakpor \& Asmah [15]). It plays a very critical part of agricultural growth and development. The system allows farmers to meet their needs and economies of scale through the uses of modern technologies that enable them to improve their production and market. Equally, agricultural loan is an effort to increase agricultural yield or output through enabling farmers to achieve his/ her socioeconomic and development objectives. In addition, the availability of the bank loan supply leads poor farmers to be efficiently played a vital role in the economy (Onyechanya \& Ukoha [16]; Eyo [17]).

Relationship between Bank Loan Supply and Crop Cultivation. The relationship between the profitability of the loan compared to farm output of a single and multiple bank loan supply system has been eatablished. Chisasa [19] revealed a positive result between bank loand and agricultural output in South Africa. In another study, Chisasa [1] reported a positive result on loan and Crop cultivation in South Africa. Tibi and Edebiri [20] reported a positive and significant relationship between bank loan supply and agricultural production through investigation of farmers' access to microloan and poverty alleviating in the Ethiope East Area of Delta State Nigeria. Ahiakpor and Asmah [15] reported a positive relationship between bank loan supply and Crop cultivation in Nigeria. Chisasa and Makina [21] revealed a positive finding between loan and agricultural production in South Africa. On the other hand, Faridi [22] reported a negative result from his study entitled finance and agricultural export in Pakistan. Additionally, Adetiloye [23] reported a negative relationship between the loan and Crop cultivation in Nigeria. Also, Chisasa [19] studied the econometric bank lending analysis and Crop cultivation in South Africa. Ammani [24] reported positive results in his study entitled to investigate the relationship between formal loan supply and agricultural production in Nigeria..

Hypothesis 1: Is there any relationship between bank loan supply and Crop cultivation in Nigeria?

Land Size. Land can be seen as a major factor in agricultural production. Farmland refers to a fertile portion of soil being utilized for a purpose of crop planting and space occupied for the rearing of animals, poultry, fisheries and forest reservations. It is also comprised of pasture. It is equally, remains a factor of production and served as a pillar of some kind of agricultural production, including processing and marketing (Kan, Haim, RapeportRom \& Schechter [26]). Similarly, land size is a gift from Allah to mankind for crop growing and animal rearing as a source of comfort, safety, and quality of life. It is also a fundamental element of plant and animal life.

Additionally, it is a fundamental resource for ensuring agricultural production and security (Chisasa [11]). Farmland has an important feature in making the advancement of agricultural production and economic growth. On the other hand, if there is no access to land, agriculture cannot adequately develop, even if and only if technical expertise, financing or marketing are available. Therefore, agricultural enterprises and financial institutions need to support the existence of a minimum level of land size development. Since, land size has featured the attainment of long-term profitability in agriculture and agro-business activities (Ngaruko [27]).

Relationship between Land Size and Crop Cultivation. Land size can be determined as a pillar of agricultural production in terms of sustainable life and socioeconomic growth. It is also, remains the ingredient of agriculture as well as other aspects of economic growth and maturity (Chisasa [28]). This indicates that land size under organic agriculture is now over twenty-six million hectares globally. According to, the size of the land size determines the significant level of the agricultural commercialization, household work as well as bank decision on bank loan supply ratio (Mohammed, Bashir \& Ogunbado [29]).

Additionally, Chisasa [1] established a positive relationship between land size and Crop cultivation in South Africa. Equally, Onyencshenya and Ukala [16] revealed that land size is positively related to the agricultural input and output. Chisasa [11] revealed a positive result between the relationship between land and 
Crop cultivation in South Africa. On the other hand, Davidova, Fredriksson, reported a negative result between land size and farmers' output from the five new European Union (EU) Member States. Equally, Bhalla and Roy [30] reported a positive relationship between Crop cultivation and the role of land quality and further concluded that the study stylized the inverse relationship between farm size and output of agricultural commodities per hectare due to the omission of soil quality. Also, the study reported positive a significant relationship between farm size and Crop cultivation in Bangladesh, Peru, and Thailand.

Trukhachev, Ivolga and Lescheva [31] established a positive relationship between land and Crop cultivation in Russian land reforms in the 1990s. They further argued that diversification of forms of property is to established conditions for multi-functional farming and sustainable condition of rural development. Similarly, Holden and Otsuka [32] reported the relationship a positive between land size and Crop cultivation in their study on the importance of land tenure and land market with population pressure and intensification of land in Africa. Consequently, due to the undervalued land size in some countries such as Ukraine, Russia, Brazil, Argentina, Paraguay, and several African countries which lead China and India to undertake a systematic investment in technology.

Hypothesis 2: Is there any relationship between land size and Crop cultivation in Nigeria?

Technology. Technology can refer to the facilities use to standardize the lifestyle of the individual or group of people to fill the necessary prerequisite for the modern style of production. The necessary facilities in terms of production and distributions include; human capital and schools for labor and farmer training, farmers' income, hospital, good road, market, modern equipment among others (Agatana \& Kalu [5]. Furthermore, technology can be described as modern farming science and employ technology to improve agricultural cultivation. Among the modern farm equipment and machinery include storage facilities, tractors, harvesters, planters, fertilizer, insecticides, farmer education and training, extension workers among others. Besides, the presence of reliable technology increased both outputs per capita and output per unit of land. Hence, farm facilities are the key players by reducing transaction costs in terms of input, output, processing, and marketing of agricultural activities within (Murphy [33]).

Relationship between Technology and Crop Cultivation. It is highly recognized that technology in agricultural activities remains the necessary ingredients for pre-condition for the gathering of capital and a rise in Crop cultivation (Mohammed et al. [29]). This is related to the improvement of the technology of the rural communities in terms of providing modern farming equipment and technologies that include: electricity, health centers, transportation and communication among others. Ammani [24] reported a positive and significant relationship between technology and agricultural cultivation in Nigeria. Chisasa [1] established a negative relationship between human labor as technology and Crop cultivation on the performance of smallholder farmers in South Africa.

Felloni, Wahl, Wandschneider, and Gilbert studied revealed mixed results on the relationship between technology and Crop cultivation. Temu, Nyange, Mttee, and Kashasha [34] reported a negative relationship between farm technology and Crop cultivation in Tanzania. Also, Ngaruko [35] established a negative relationship between educations and Crop cultivation in Tanzania. Okuthe, Ngesa and Ochola established a positive relationship between technological technology and the growths of Crop cultivation of sorghum in South Western Kenya.

Hypothesis 3: Is there any relationship between technology and Crop cultivation in Nigeria?

Cost-Plus. Cost-plus or mark-up (Murabahah finance) is defined as a financing for the purchase of goods (farm input) and services and resale the input of the client or customer (farmer) that allows the customer (farmer) to make purchases without having to take out a loan and pay interest (Saddiqi, 2006). Cost-plus transaction (finance) is conforming to the Shariah and free from Riba, excessive Gharar and other prohibitions. The most underlying cause of initiating Cost-plus financing was to aid the small scale farmers (poor farmers) and traders who lack money to sustain crops and their trading (Sardam, Azeem, Hassan \& Bakish [37]). Consequently, modern Islamic financial institutions used Cost-plus financing as a modern value of financing mostly trading and agriculture. Since, it is an essential element of control poverty, unemployment, inflation as well as a promoter of Islamic financial discipline in the fields of trade and agricultural production (Saddiqi [36]; Ayub [38]).

Relationship between Cost-Plus and Crop Cultivation. Mohsin [39] studied the practice of Islamic banking products in the agricultural sector of the Republic of Sudan and reported that Cost-plus has a positive relationship with agricultural activities. Similarly, Obaidullah and Mohamedsaleem [40] established a positive relationship between Cost-plus and agricultural financing in Sri-Lanka. Hilmy [41] reported a positive impact of Cost-plus financing in paddy land cultivation of Sri Linka. Eventually, Cost-plus financing is among the major products of Islamic banking globally that governed and controlled by various rules of Shariah. More so, Mastoor established a positive relationship between Costplus in financing paddy land cultivation in Afghanistan. Mohammed and Hussien [43] investigated the financial stand of wheat growers of commercial finance in the Gezira region of Sudan republic. Saqib, Nazeer, Khan, and Zafar [44] reported a significant relationship on the application of the Cost-plus Islamic banking instrument for the Sugarcane Industry in Developing Countries.

Hypothesis 4: Is there any relationship between costplus and Crop cultivation in Nigeria? 


\section{INDEPENDENT VARIABLES}

DEPENDENT VARIABLE

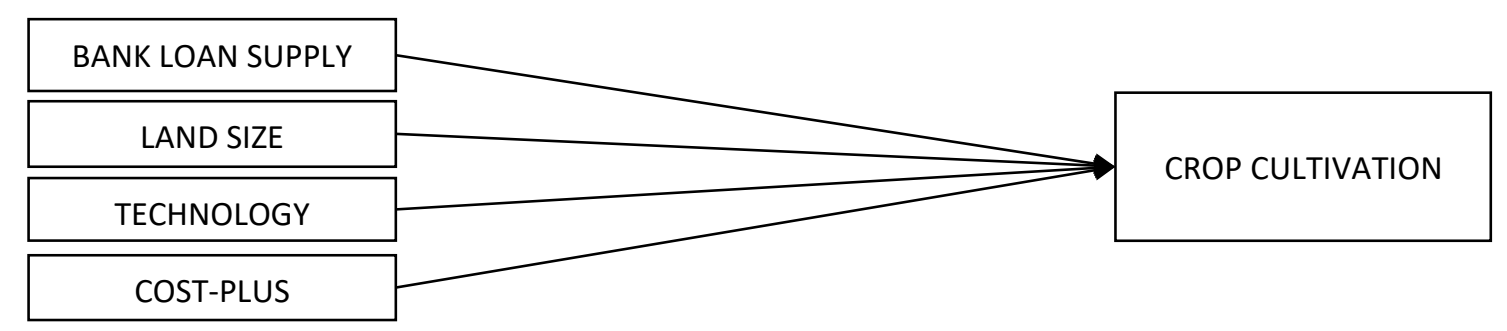

Figure 1 Theoretical Frame Work

Source: Authors analysis

The above theoretical framework as indicated the directions of the arrows which explained the relationship between agricultural production input (bank loan supply, land size, technology, and Cost-Plus,) and agricultural production output (Crop cultivation) as well this is in line with the theory of production based on Cobb-Douglas (1929) Production function established the relationship between input (bank loan supply, land size and technology, and Cost-Plus) and output (Crop cultivation) (Chambers [6]; King \& Levine [9]; Anthony [13]; Chisasa [1]).

Underpinning Theory. This research is relevant to the theory of production as the basic objective of the agricultural production is to ensure sustainable production input and output for the economic growth (Chisasa [1]). Therefore, it is relevant here to consider the theory of production based on the production function of Cobb Douglas (1929), to work as an underpinning theory in this research. Since, the theory of production is concerned with the measurement of the physical production through measuring the changes in the determinants or factors or input of production of the volume of production output. Also, the rural loan market theory came with the assertion that the charging of interest by the conventional financial institutions is contributing to the failure of the output. On the other hand, the availability of a less interest rate is leading to the technical increase in the Crop cultivation due to the efficient and technical innovation in the farm input. Theoretically, the framework of the research can be established the relationship between the Crop cultivation and bank loan supply, Cost-Plus, land size and technology as seen in figure 1.
Methodology. This study adopted a quantitative research approach to assess the structural relationship among the variables that include bank loan supply, land size, technology, and Crop cultivation. Also, the study was considered Partial Least Squares modeling (Smart PLS) of structural equation modeling (SEM) for data analysis to test several hypotheses formulated from the literature reviewed. The data were analyzed and interpret statistically. Also, the population of the study was the 511,780 registered farmers of Kano State with 760 sample sizes based on Krejcie and Morgan [45] and a systematic random sampling technique was proposed upon individual farmers as the unit of analysis as well as the respondent of the research questionnaire. Furthermore, this research considered Smart PLS-SEM to analyst the primary data captured through questionnaires for analysis.

Questionnaire Rate of Response. An aggregate number of 760 questionnaires were distributed. Also, a total number of 532 questionnaires were retrieved from 760 initially distributed questionnaires to the participated farmer. Equally, 87 were rejected from the 532 returned questionnaires, due to the insufficient answers in the filled questionnaires. Furthermore, 447 questionnaires remained valid for the current research analysis and it covers a total of $59 \%$ participation of the targeted farmers, which is enough as Stated by Hair, Black, Babin, and Anderson.

Descriptive Analysis of the Latent Constructs. This section concentrated primarily on descriptive statistics for the latent variables. Specifically, the study used Descriptive statistics on computing means and standard deviations with the latent variables as indicated in Table 1.

Table 1 Descriptive Statistics

\begin{tabular}{|l|c|c|c|}
\hline \multicolumn{1}{|c|}{ Variable } & N & Mean & Std. Deviation \\
\hline CROP CULTIVATION & 447 & 3.875 & 0.877 \\
\hline BANK LOAN SUPPLY & 447 & 4.036 & 0.828 \\
\hline LAND SIZE & 447 & 1.687 & 0.727 \\
\hline TECHNOLOGY & 447 & 3.967 & 0.810 \\
\hline COST-PLUS & 447 & 4.270 & 0.818 \\
\hline
\end{tabular}

\section{Source; Authors analysis}

Meanwhile, the above Table explained the entire mean of the study latent variables which indicated that mean ranged between 3.875 and 4.270. Furthermore, the mean and standard deviation for the crop cultivation 
remain 3.875 while the standard deviation 0.877 whereas, the Bank loan supply is 4.036 and 0.828 respectively. Similarly, 1.687 and 0.727 represented the mean and standard deviation of the land size respectively. Equally, 3.967 and 0.810 represented the mean and standard deviation of the technology. Cost-plus indicated that 4.270 and 0.818 represented the Mean and standard deviation respectively.

Internal Consistency Reliability. The Internal consistency reliability of the current research considered the Composite reliability coefficient to ascertain the internal consistency of the adapted measurement. Gotz, Liehr-Gobblers and Krafft reported that the Composite reliability coefficient measure is less biased compared to the Cronbach's alpha coefficient. Since the Composite reliability coefficient assumes that all the research items are equally contributed to the construct without specifying the level of individual participation to the loadings as such, Crop Produc. $=0.888$, Bank Loan Supply =
0.753 , Land Size $=0.766, \mathrm{TECHN}=0.796$ and Cost Plus = 0.849 , respectively.

Discriminant Validity. Fornell and Larcker [56] argued that discriminant validity used to be achieved through Average Variable Extracted (AVE). This achievement used to come across comparing the statistical correlations of the latent constructs by considering the square roots of the average variance extracted. Equally, discriminant validity was determined through conditions of Chin's [48] which is the criterion by comparing the indicator loadings with other reflective indicators in the cross-loading table. Consequently, 0.50 and above are acceptable in respect of the rule of thumb in evaluating the statistical discriminant validity (Fornell \& Larcker, [47]). Table 2 equally indicates that the square root regarded as the average variances extracted all were above the correlations between the research latent constructs. This is in line with the suggestion of Fornell and Larcker [47]. Based on this the current research had sufficient discriminant validity.

Table 2 Latent Variable Correlations (Discriminant Validity)

\begin{tabular}{|l|c|c|c|c|c|}
\hline \multicolumn{1}{|c|}{ Variable } & 1 & 2 & 3 & 4 & 5 \\
\hline 1. CROP CULTIVATION & 0.784 & & & & \\
\hline 2. BANK LOAN SUPPLY & 0.290 & 0.778 & & & \\
\hline 3. LAND SIZE & 0.072 & -0.067 & 0.798 & & \\
\hline 4. TECHNOLOGY & 0.573 & 0.187 & 0.090 & 0.754 & \\
\hline 5. COST-PLUS & 0.112 & 0.333 & -0.287 & 0.038 & 0.860 \\
\hline
\end{tabular}

Note: the values in bold represent the square root of the average variance extracted (AVE) across diagonals, while off-diagonal values are the correlations between variables

Source: Authors computations

Findings. Having satisfied with the measurement model, this research also assessed the structural model as the critical assessment condition. The current research used standard bootstrapping criteria with a total number of 5000 bootstrap statistical samples and 447 cases in finding the significant level of the path coefficients (Hair [46]).

After the full model assessment, Hypothesis1 predicted that there is a positive and significant relationship between bank loan supply and Crop cultivation. Thus, findings shows that bank loan supply had a positive and significant relationship with Crop cultivation ( $\beta=0.179, \mathrm{t}=3.607, \mathrm{p}<0.01$ ), Similarly, in examining the relationship between land size and Crop cultivation, the result indicated that land size had a negative relationship with Crop cultivation which is not supported Hypothesis $2(\beta=0.049, t=0.195, p<0.01)$. While Hypothesis 3 predicted that there is a positive and significant relationship between technology and Crop cultivation. And the finding had supported the proposed Hypothesis $(\beta=0.533, t=12.204, p<0.01)$ which indicated that there is a positive and significant relationship between tech. and Crop cultivation. Cost-plus has a positive relationship with crop cultivations as such it was supported by path coefficients $(\beta=-0.074, t=0.783, p<$ 0.038 ) that is the result supported Hypothesis 4. Equally, the following Table 3 summarises the findings from Hypothesis (H) 1-4.

Table 3 Summary of Hypotheses Testing

\begin{tabular}{|c|l|c|c|c|c|c|}
\hline Hypothesis & \multicolumn{1}{|c|}{ Relationship } & beta values & Standard Error & $\mathrm{t}$ values & $\mathrm{p}$ values & Decision \\
\hline H1 & BANK LOAN SUP -> CROP PROD. & 0.179 & 0.050 & 3.607 & 0.000 & Supported \\
\hline H2 & LAND SIZE -> FARM PROD. & 0.049 & 0.057 & 0.860 & 0.195 & Supported \\
\hline H3 & TECH. -> FARM PROD. & -0.533 & 0.044 & 12.204 & 0.000 & Not Supported \\
\hline H4 & COST-PLUS -> AGRIC & 0.163 & 0.041 & 3.999 & 0.000 & Supported \\
\hline
\end{tabular}

Source: Authors analysis

Assessment of Variance Explained in the Endogenous Latent Variables. The $R$-squared value represents the proportion of variation in the dependent variable(s) that can be explained by one or more predictor variables (Hair et al. [46]). According to Falk and Miller [49], the Rsquared value of 0.10 is the minimum level. Consequently, 
PLS-SEM described $R$-squared values of 0.67 which is sufficient as in line with the study of Chin [48]. Hence, endogenous latent variables and $R$-squared values can be seen in table.4.

Table 4 Variance Explained in the Endogenous Latent Variables

\begin{tabular}{|l|c|}
\hline \multicolumn{1}{|c|}{ Latent Variable } & Variance Explained (R2) \\
\hline Crop cultivation & 0.37 \\
\hline
\end{tabular}

Source: Authors analysis

As shown in table 4, the current research model explained 0.37 as a total existing variance concerning Crop cultivation. This indicated that the four sets of exogenous latent variables (bank loan supply, Cost-plus, land size, and technology ) entirely explained the accumulated variance of 0.37 or $37 \%$ on Crop cultivation. Therefore, endogenous latent variables of this paper have achieved the acceptable levels of the $R$-squared values at a moderate level (Chin's [48]).

Implications. The finding of the current research has practical implications for the Nigerian agricultural sector. Firstly, the results suggest that perceptions of Nigerian farmers on the relationship between farm input and output promoting agriculture in Nigeria. Also, Nigerian farmers can make considerable efforts in utilizing agricultural finances to increase crop cultivation. Secondly, the findings suggest that farm inputs were related to Crop cultivation. Thus, financial institutions could increase the likelihood of farmers toward engaging in facilities more especially free interest farm facilities. Therefore, agricultural input strategy should be given serious consideration in the agricultural sector of Nigeria.

Taken together, the present study has provided additional evidence to the growing body of knowledge on the relationship between bank loan supply, Cost-plus, land size, technology, and Crop cultivation. Results from this study supported the key theoretical propositions. In particular, the current study has successfully answered all of the research questions and objectives despite some of its limitations. Furthermore, the theories stipulated that Crop cultivation is a function of technical efficiency of bank loan supply, Cost-plus, land size, and technology for economic growth and development. In addition to the theoretical contributions, the results from this study provide some important practical implications to the Nigeria government through the ministry of agriculture, farmers cooperative, subsistence, and commercial farmers, agro-business and agro-allied industries, stakeholders and managers, both public, privates and nongovernmental organizations (NGOs).

Conclusions. The consideration of PLS path modeling toward testing this theoretical model is in line with the determination of path coefficient significance which was presented as major findings of this research. Meanwhile, the self-report method was used and provided reasonable statistical support to the relationship between agricultural input and outputs as the research variables. Similarly, the path coefficients revealed a positive and significant relationship between bank loan supply and Crop cultivation. On the other hand, it revealed a negative relationship between farmland and Crop cultivation. While it revealed a positive and significant relationship between technology and Crop cultivation. Consequently, future research should retest the relationship between land size and Crop cultivation in Nigeria.

\section{References:}

1. Chisasa, J. (2014). An Econometric Analysis Of Bank Lending And Crop cultivation In South Africa: A Survey Approach. Journal of Applied Business Research (JABR), 31(1), 163-174.

2. Ogunbado, A. F \& Ahmed, U. (2015). Bay' Salam as an Islamic Financial Alternative for Agricultural Sustainability in Nigeria. Journal of Islamic Economics, Banking and Finance (JIEBF), 11, 4.

3. Phillip, D., Nkonya, E., Pender, J. \& Oni, O. (2009). Constraints to increasing agricultural cultivation in Nigeria: A review (No. 6). International Food Policy Research Institute (IFPRI).

4. World Population Review (2020). Nigerian population 2020. Retrieved from http://worlpopulationreview.com/countries/nigeria-population.

5. Atagana \& Kalu, C. (2014). Evaluation of Fund for Agricultural Loan Guarantee Scheme in Nigeria: A Tool for Economic Growth and Development.

6. Chambers, R. G. (1988). Applied production analysis: a dual approach. Cambridge University Press.

7. Collier, P. \& Dercon, S. (2014). African Agriculture in 50Years: Smallholders in a Rapidly Changing World? World Development, $63,92-101$.

8. Ahungwa, G., Haruna, U. \& Abdusalam, R. (2013). Trend Analysis of the Contribution of Agriculture to the Gross Domestic Product of Nigeria (1960-2012).

9. King, R. G. \& Levine, R. (1993). Finance and growth: Schumpeter might be right. The quarterly journal of economics, 717-737.

10. Akoum, I. F. (2008). Globalization, growth, and poverty: the missing link. International Journal of Social Economics, 35(4), 226238.

11. Chisasa, J. A. (2014b). Diagnosis of Rural Agricultural Loan Markets In South Africa: Empirical Evidence From North West And Mpumalanga Provinces.

12. Ayegba, O. \& Ikani, D. I. (2013). An Impact Assessment of Agricultural Loan on Rural Farmers in Nigeria. Research Journal of Finance And Accounting, 4(18), 80-89. 
13. Anthony, E. (2010). Agricultural Loan and Economic Growth in Nigeria: An Empirical Analysis. Approach with Special Reference to Poverty Eradication in Pakistan. International Journal of Economics, Management, and Accounting, 20(1).

14. Simtowe, F., Zeller, M. \& Diagne, A. (2009). The Impact of Credit Constraints on the Adoption of Hybrid Maize in Malawi. Review of Agricultural and Environmental studies, 90(1), 5-22.

15. Ahiakpor, F. \& Asmah, E. (2012). A Brief Survey of the Literature on Microfinance and Agriculture. Faculty of Social Sciences, University of Ghana, Legon, 9(1), 73.

16. Onyenucheya, F. \& Ukoha, O. (2007). Loan repayment and loan worthiness of farmers under the Nigerian Agricultural Cooperative and Rural Development Bank (NACRDB). Agricultural Journal, 2(2), 265-270.

17. Eyo, E. O. (2008). Determinants of Success of Micro-Finance Schemes Serving the Agricultural Sector in Akwa Ibom State, Nigeria. Pakistan Journal of Social Sciences, 5(2), 173-176.

18. Adetiloye, K. A. (2012). Agricultural financing in Nigeria: an assessment of the Agricultural Loan Guarantee Scheme Fund (ACGSF) for food security in Nigeria (1978-2006). Journal Economics, 3(1), 39-48.

19. Chisasa, J. (2015). An Econometric Analysis of Bank Lending And Crop cultivation In South Africa. A Survey Approach. Journal of Applied Business Research, 31(1), 163.

20. Tibi, K. \& Edebiri, F. (2015). Access To Microloan-A Sure Way Of Breaking The Vicious Circle Of Poverty Among Farmers In Ethiope East Local Government Area, Delta State, Nigeria, 2, 8 PP, 1275-1184.

21. Chisasa, J. \& Makina, D. (2014). A diagnosis of rural agricultural loan markets in South Africa: empirical evidence from North West and Mpumalanga provinces. Banks and Bank Systems, 9(2), 100-111.

22. Faridi, M. Z. (2012) reported a negative result between finance and agriculture in Pakistan. Retrieved from http://www.iiste.org/Journals/index.php/PPAR/article/viewFile/24951/25554.

23. Adetiloye, K. A. (2012). Agricultural financing in Nigeria: an assessment of the Agricultural Credit Guarantee Scheme Fund (ACGSF) for food security in Nigeria (1978-2006). Journal Economics, 3(1), 39-48.

24. Ammani, A. A. (2012). Research into the Relationship between Agricultural Production and Formal Loan Supply in Nigeria. International Journal of Agriculture and Forestry, 2(1), 46-52.

25. Kaleem, A., \& Abdul Wajid, R. (2009). Application of Islamic banking instrument (Bai Salam) for agriculture financing in Pakistan. British Food Journal, 111(3), 275-292.

26. Kan, I., Haim, D., Rapaport-Rom, M. \& Shechter, M. (2009). Environmental amenities and optimal agricultural land use: The case of Israel. Ecological Economics, 68(6), 1893-1898.

27. Ngaruko, D. D. (2014). Determinants of Demand for and Repayment of Bank loan supply in Economies with Market Coordination Failures: A Tanzanian context. African Journal of Economic Review, 2(2), 95-124.

28. Chisasa, J. A (2014c). Diagnosis of Rural Agricultural Loan Markets in South Africa: Empirical Evidence from northwest And Mpumalanga Provinces. Banks and Bank Systems, 9(2).

29. Mohammed, A. I., Bashir, A. A. \& Ogunbado, T. (2016). The Viability of Salam Finance in the Growth of Agricultural Production in Kano State, Nigeria. Asian Journal of Multidisciplinary Studies, 4(12).

30. Bhalla, S. S. \& Roy, P. (1988). Mis-specification in Crop cultivation analysis: the role of land quality. Oxford Economic Papers, 40(1), 55-73.

31. Trukhachev, V., Ivolga, A. \& Lescheva, M. (2014). Enhancement of Land Tenure Relations as a Factor of Sustainable Agricultural Development: Case of Stavropol Krai, Russia. Sustainability, 7(1), 164-179.

32. Holden, S. T. \& Otsuka, K. (2014). The roles of land tenure reforms and land markets in the context of population growth and land-use intensification in Africa. Food Policy, 48, 88-97.

33. Murphy, A. J. (2011). Farmers' markets as retail spaces. International Journal of Retail \& Distribution Management, 39(8), 582597.

34. Temu, A. E., Nyange, D., Mattee, A. Z. \& Kashasha, L. K. (2013). Assessing Rural Services, Technology and their Impact on Agricultural Production, Marketing and Food Security in Tanzania.

35. Ngaruko, D. D. (2014). Determinants of Demand for and Repayment of Bank loan supply in Economies with Market Coordination Failures: A Tanzanian context. African Journal of Economic Review, 2(2), 95-124.

36. Siddiqi, M. N. (2006). Islamic banking and finance in theory and practice: A Survey of State of the Art. Islamic Economic Studies, 13(2), 1-48.

37. Sardar, A., Azeem, M. M., Hassan, S. \& Bakhsh, K. (2013). Comparison of efficiency between pure Islamic banks and Islamic bank windows and role of Islamic banking in agriculture sector. Pak. J. Agri. Sci, 50(1), 155-161.

38. Ayub, M. (2007). Understanding Islamic finanance. West Sussex Willey \& Sons Ltd.

39. Mohsin, M. I. A. (2005). The practice of Islamic banking system in Sudan. Journal of Economic Cooperation, 26 (4), 27-50.

40. Obaidullah, M. \& Mohamed-Saleem, A. (2008). Innovations in Islamic microfinance: lessons from Muslim Aid's Sri Lankan experiment. Islamic Development Bank, Jeddah, KSA.

41. Hilmy, H. A. (2013). Introducing Salam as an alternative financing tool for paddy field cultivation in Sri Lanka (special reference to Eastern province). Soth Eastern University of Sri Lanaka.

42. Mastoor, S. A. (2014). Islamic Banking System in Afghanistan (No. 0200302). International Institute of Social and Economic Sciences.

43. Mohammed, H. S. E. A. \& Hussien, A. I. M. (2012). The Finance Of Wheat In Gezira Scheme, Sudan. International Working Paper Series, Paper N.12/03 
Електронне наукове фахове видання з економічних наук “Modern Economics», №19 (2020), 126-134 https://modecon.mnau.edu.ua | ISSN 2521-6392

44. Saqib, L., Nazeer, N., Khan, K. \& Zafar, M. A. (2013). Application of Islamic banking instrument (Murābaha) for sugarcane industry in developing countries. Journal of Islamic Economics, Banking and Finance, 9(1), 89-106.

45. Krejcie, R. V. \& Morgan, D. W. (1970). Determining Sample Size for Research Activities. Educational and Psychological Measurement, 30, 607-610.

46. Hair, J. F., Black, W. C., Babin, B. J. \& Anderson, R. E. (2010). Multivariate data analysis. A global perspective. New Jersey: Pearson Education, Inc.

47. Fornell, C. \& Larcker, D. F. (1981). Evaluating Structural Equation Models with unobservable variables and measurement error. Journal of Marketing Research, 18, 39-50.

48. Chin, W. W. (1998a). The partial least squares approach to structural equation modeling. In G. A. Marcoulides (Ed.)/ Modern Methods for Business Research (p. 295-336). Mahwah, New Jersey: Laurence Erlbaum Associates.

49. Falk, R. F. \& Miller, N. B. (1992). A primer for soft modeling. Ohio: The University of Akron Press.

50. Index Mundi (2019). Agricultural, value add (Current US\$̧) - Country Rankings. Retrieved from https://www.indexmundi.com/facts/indicators/NV.AGR.TOTL.CD/rankings.

51. Kshama, A. V. \& Santha, A. M. (2019). A comparative study on the performance of various types of loans availed by the farmers in Thiruvananthapuram district. Economic Affairs, 64(4), 689-694.

52. Yin Y. \& Li Y. (2019) The Innovative Aid Mode of Agriculture Going Global to Promote Investment: CGCOC and Jiangxi Ganliang. In: Huang M., Xu X., Mao X. (eds) South-south Cooperation and Chinese Foreign Aid. Palgrave Macmillan, Singapore.

53. Narayanan, S. \& Mehrotra, N. (2019). Waivers and Bank Credit: Reflections on the Evidence and the Way Forward. Vikalpa, 44:4, 198-210. 